\title{
A study of the career development of male and female dental practitioners
}

\author{
J. T. Newton, ${ }^{1}$ N. Thorogood, ${ }^{2}$ and D. E. Gibbons, ${ }^{3}$
}

\begin{abstract}
Aim The aim of the study was to determine differences between male and female dental practitioners in the positions they occupy within their employment, and to analyse the correlates of such differences.

Method Postal questionnaire survey of a 1 in 10 sample of individuals taken from the General Dental Council register. Results Female dental practitioners occupy lower positions in the employment hierarchies of the Community Dental Service and the Hospital Dental Service. Women general dental practitioners are significantly less likely to be sole proprietor of, or a partner in, a general practice.

Ownership of a general practice is related to: sex, age, number of years qualified, number of children, and hours worked.

Consultants in the Hospital Dental Service are more likely to be male, older, to have been qualified longer and (obviously) to hold more additional qualifications than their non-consultant colleagues. Senior Dental Officers and Directors of the Community Dental Service are more likely to be male, work longer hours and (again obviously) to hold more additional qualifications than Community Dental Officers.
\end{abstract}

Conclusions Differences exist between male and female dental practitioners in the positions they occupy within employment hierarchies. Age, length of time since qualification and the acquisition of additional qualifications are consistently found to differentiate dental practitioners' status.

$\mathrm{T}$ he number and proportion of women entering the profession of dentistry has increased during the past two decades as evidenced by registrations with the General Dental Council. The proportion of registrations by women has risen from one quarter of new entrants in 1975, to over one third in 1985, to one half in $1991 .^{1,2,3}$ There have been a number of studies which have examined differences between male and female dental practitioners in their work patterns. Spencer and Lewis ${ }^{4}$ suggested that males and females differed in their hours of work (women being more likely to work part-time) and in their practice setting (women being more likely to hold salaried positions). Similarly McEwen and Seward ${ }^{2}$ reported that although two-thirds of their sample of female dental practitioners worked in general dental practice the proportion of women working as principals was low (46\% of those working in general practice) and had shown little increase over a period of 10 years. ${ }^{1}$ McEwen and Seward went on to suggest that some women preferred not to take on the responsibility of owning

\footnotetext{
${ }^{*}$ Lecturer in Psychology in Relation to Dentistry, ${ }^{2}$ Lecturer in Sociology in Relation to Dentistry, ${ }^{3}$ Professor and Head of Department, Department of Dental Public Health \&Oral Health Services Research, Guy's, King's and Thomas' School of Medicine \& Dentistry, Floor 18, Guy's Tower, Guy's Hospital, London SE1 9RT ${ }^{*}$ Correspondence to: DrJ T Newton

REFEREED PAPER

Received 19.03.99; accepted 28.10.99

(C) British Dental Journal 2000; 188: 90-94
}

and managing their own practice, and that, furthermore, some male practitioners were reluctant to enter into a business partnership with a woman. ${ }^{5}$ Research in the United States has found a similar trend in practice ownership. The American Dental Association found that males were significantly more likely to own or have a share in ownership of their practice. ${ }^{6}$ More recent research suggested that male practitioners earn significantly more money than female practitioners. ${ }^{7}$ Such differences appear to be most marked after women have children. ${ }^{8}$

The aims of the present study are to determine whether differences exist between male and female dental practitioners in the positions they occupy within their employment, and to analyse the correlates of such differences. This research both replicates and extends previous research in this area. It is more than 10 years since the publication of Seward and McEwen's report into the working practices of women dentists. This study seeks to examine any changes that have occurred in the working practices of male and female practitioners. Furthermore this study will extend that research by the addition of a comparison group of male practitioners and by examining the relationship between occupational status and variables which may be expected to predict status such as: time since qualification, age, having taken a career break etc.

\section{Method}

A questionnaire survey of a random sample of one in ten dentists taken from the General Dental Council register was carried out.

\section{Sample}

A random sample of 2,700 dental practitioners was taken by selecting a random starting point in the first ten names in the register then sampling every tenth name from that one. The sample size estimate is based upon the ability to estimate a difference in proportions. Previous research in the USA has shown that the proportion of male dentists who are sole proprietors of dental practices is $60 \%$, the comparative figure for female dentists being $45 \% .^{6}$ If a similar difference were present in the UK population, assuming a significance level of 0.05 and a power of $90 \%$, the sample size required accurately to identify this difference is 250 males and 250 females. The proposed sample size will allow us to identify this difference accurately with due allowance for differences in the proportion of males and females in the overall sample.

\section{Questionnaire}

The questionnaire developed for this study was based upon the original questionnaire used by McEwen and Seward. ${ }^{5}$ The questionnaire was pilot tested on a sample of 50 dentists, following which modifications were made to improve wording and clarity. The questionnaire included sections covering the following areas:

- Demographic characteristics of respondent.

- Current working practice (including employment position and speciality). 
- Career breaks (including number of breaks, duration and reason for taking break).

\section{Procedure}

A copy of the research questionnaire was sent to each participant, together with a cover letter explaining the purpose of the research and a reply paid envelope. After 1 month, any dentists who had not replied were sent a further letter requesting their assistance, together with another copy of the questionnaire and a reply-paid envelope. In addition letters were published in the dental press requesting readers to complete questionnaires. Previous research with this group and using this methodology $y^{2,5}$ achieved an initial return rate of $65 \%$, which was increased to $75 \%$ following a reminder letter.

\section{Results}

Replies were received from 1,798 dental practitioners (response rate $66.6 \%) ; 1,153$ males $(64.1 \%)$ and 580 females (32.3\%), 65 respondents did not state their sex on the form. The analyses reported here will exclude those respondents who were not working in General Dental Practice, the Community Dental Service or the Hospital Dental Service. This reduces the sample size for this study to a total of 1,455 individuals ( 967 male; 488 female). On average the males in the sample were older than the females (mean age males $46.85, \mathrm{SD}=$ 13.48; mean age females $40.32, \mathrm{SD}=12.6$; $t=9.69 P<0.001)$. The average number of years since qualification also differed significantly between the sexes. For the male respondents the average number of years since first qualifying as a dentist was 22.86 years ( $\mathrm{SD}=12.55$ years), and for female respondents the average was 16.65 years $(\mathrm{SD}=10.73$ years $)$. Of the 1,455 individuals, $74(5.1 \%)$ had qualified in dentistry in a university outside the UK.

The proportion of females in the present sample is slightly higher than that which would be expected. The Dentists Register (1999) reports that $30.20 \%$ of those registered are women. Dentists who qualified outside the UK are under represented in the current data set, $15.12 \%$ of those registered with the GDC have non-UK first qualifications in dentistry.

Three areas of dental practice are presented: general dental practice, hospital dental practice, and community dental practice. Table 1 shows the numbers and proportion of respondents (as a

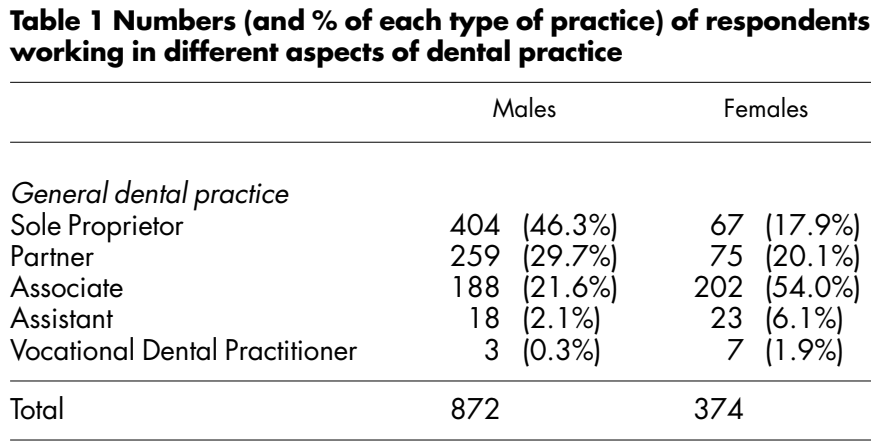

Hospital dental service

\begin{tabular}{lrlrl} 
Consultant & 32 & $(68.1 \%)$ & 5 & $(17.9 \%)$ \\
Senior Registrar & 5 & $(10.6 \%)$ & 7 & $(25.0 \%)$ \\
Specialist Registrar & 1 & $(2.1 \%)$ & 3 & $(10.7 \%)$ \\
Registrar & 5 & $(10.6 \%)$ & 5 & $(17.9 \%)$ \\
Senior House Officer & 4 & $(8.5 \%)$ & 8 & $(28.6 \%)$ \\
\hline Total & 47 & & 28 & \\
\hline
\end{tabular}

Community dental service

Director

Senior Dental Officer

Community Dental Officer

Total $48 \quad 86$

$11(22.9 \%) \quad 6 \quad(7.0 \%)$

$16(33.3 \%) \quad 25(29.1 \%)$

$21(43.8 \%) \quad 55(63.9 \%)$

Table 2 Comparison of practice owners and non-practice owners on key demographic variables

\begin{tabular}{|c|c|c|c|}
\hline Variable & $\begin{array}{l}\text { Owns practice } \\
(N=805)\end{array}$ & $\begin{array}{l}\text { Does not own practice } \\
(N=433)\end{array}$ & \\
\hline Sex & $\begin{array}{l}\text { Males }=663 \\
\text { Females }=142\end{array}$ & $\begin{array}{l}\text { Males }=201 \\
\text { Females }=232\end{array}$ & $\begin{array}{l}\text { chi-squared = 170.79, } \\
P<0.001\end{array}$ \\
\hline Age & $\begin{array}{l}\text { Mean }=45.56 \text { years } \\
(S D=10.76)\end{array}$ & $\begin{array}{l}\text { Mean }=37.10 \text { years } \\
(S D=12.35)\end{array}$ & $t=12.32, P<0.001$ \\
\hline Years qualified & $\begin{array}{l}\text { Mean }=21.99 \text { years } \\
(S D=9.97)\end{array}$ & $\begin{array}{l}\text { Mean }=13.72 \text { years } \\
(S D=11.09)\end{array}$ & $t=13.24, P<0.001$ \\
\hline $\begin{array}{l}\text { Additional } \\
\text { qualifications }\end{array}$ & $\begin{array}{l}\text { Mean }=0.23 \\
(S D=0.55)\end{array}$ & $\begin{array}{l}\text { Mean }=0.16 \\
(S D=0.44)\end{array}$ & $\begin{array}{l}U=158006 \\
P<0.05\end{array}$ \\
\hline $\begin{array}{l}\text { Place of } \\
\text { qualification }\end{array}$ & $\begin{array}{l}\text { UK }=763 \\
\text { Non-UK }=42\end{array}$ & $\begin{array}{l}\text { UK }=405 \\
\text { Non-UK }=28\end{array}$ & $\begin{array}{l}\text { chi-squared = 0.06, } \\
\mathrm{Ns}\end{array}$ \\
\hline Number of children & $\begin{array}{l}\text { Mean }=1.24 \\
(S D=1.24)\end{array}$ & $\begin{array}{l}\text { Mean }=0.79 \\
(S D=0.79)\end{array}$ & $\begin{array}{l}U=32638.5 \\
P<0.001\end{array}$ \\
\hline Hours worked & $\begin{array}{l}\text { Mean }=37.13 \\
\text { hours/week } \\
(S D=8.69)\end{array}$ & $\begin{array}{l}\text { Mean }=31.68 \\
\text { hours/week } \\
(S D=10.48)\end{array}$ & $\begin{array}{l}U=113484.5 \\
P<0.001\end{array}$ \\
\hline Career break & $\begin{array}{l}\text { Taken break }=275 \\
\text { Not taken a break }=530\end{array}$ & $\begin{array}{l}\text { Taken break = } 198 \\
\text { Not taken a break = } 235\end{array}$ & $\begin{array}{l}\text { chi-squared = } 15.47 \\
P<0.001\end{array}$ \\
\hline $\begin{array}{l}\text { Reading } \\
\text { professional } \\
\text { journals }\end{array}$ & $\begin{array}{l}\text { Never }=2 \\
<1 / \text { month }=62 \\
>1 / \text { month }=741\end{array}$ & $\begin{array}{l}\text { Never }=5 \\
<1 / \text { month }=68 \\
>1 / \text { month }=360\end{array}$ & $\begin{array}{l}\text { chi-squared = } 23.77 \\
P<0.001\end{array}$ \\
\hline $\begin{array}{l}\text { Postgraduate } \\
\text { courses }\end{array}$ & $\begin{array}{l}\text { None }=35 \\
1 \text { day }=62 \\
2-4 \text { days }=300 \\
5-10 \text { days }=254 \\
11+\text { days }=154\end{array}$ & $\begin{array}{l}\text { None }=32 \\
1 \text { day }=50 \\
2-4 \text { days }=165 \\
5-10 \text { days }=115 \\
11+\text { days }=71\end{array}$ & $\begin{array}{l}\text { chi-squared = } 12.98 \\
P<0.05\end{array}$ \\
\hline
\end{tabular}


Table 3 Comparison of hospital consultants and non-consultants on key demographic variables

\begin{tabular}{|c|c|c|c|}
\hline Variable & Consultant $(N=37)$ & Non-consultant $(N=38)$ & \\
\hline Sex & $\begin{array}{l}\text { Males }=32 \\
\text { Females }=5\end{array}$ & $\begin{array}{l}\text { Males }=15 \\
\text { Females }=23\end{array}$ & $\begin{array}{l}\text { chi-squared }=15.76, \\
P<0.001\end{array}$ \\
\hline Age & $\begin{array}{l}\text { Mean }=49.17 \text { years } \\
(\mathrm{SD}=8.07)\end{array}$ & $\begin{array}{l}\text { Mean } 31.34 \text { years } \\
(\mathrm{SD}=5.71)\end{array}$ & $t=11.02, P<0,001$ \\
\hline Years qualified & $\begin{array}{l}\text { Mean }=27.11 \text { years } \\
(\mathrm{SD}=8.52)\end{array}$ & $\begin{array}{l}\text { Mean }=10.43 \text { years } \\
(S D=12.12)\end{array}$ & $t=6.66, P<0.001$ \\
\hline Additional qualifications & $\begin{array}{l}\text { Mean }=1.81 \\
(S D=1.23)\end{array}$ & $\begin{array}{l}\text { Mean }=0.76 \\
(S D=0.91)\end{array}$ & $\begin{array}{l}U=919 \\
P<0.05\end{array}$ \\
\hline Place of qualification & $\begin{array}{l}\mathrm{UK}=35 \\
\text { Non-UK }=2\end{array}$ & $\begin{array}{l}\text { UK }=34 \\
\text { Non-UK }=4\end{array}$ & $\begin{array}{l}\text { chi-squared =0.15, } \\
\text { ns }\end{array}$ \\
\hline Number of children & $\begin{array}{l}\text { Mean }=2.28 \\
(S D=0.79)\end{array}$ & $\begin{array}{l}\text { Mean }=1.90 \\
(S D=1.00)\end{array}$ & $\mathrm{U}=111.5, \mathrm{~ns}$ \\
\hline Hours worked & $\begin{array}{l}\text { Mean }=46.79 \\
\text { hours/week } \\
(S D=14.5)\end{array}$ & $\begin{array}{l}\text { Mean }=44.74 \\
\text { hours/week } \\
(\mathrm{SD}=11.2)\end{array}$ & $\mathrm{U}=408.5, \mathrm{~ns}$ \\
\hline Career break & $\begin{array}{l}\text { Taken break }=14 \\
\text { Not taken a break = } 23\end{array}$ & $\begin{array}{l}\text { Taken break }=13 \\
\text { Not taken a break }=25\end{array}$ & $\begin{array}{l}\text { chi-squared }=0.11 \text {, } \\
\text { ns }\end{array}$ \\
\hline $\begin{array}{l}\text { Reading } \\
\text { professional } \\
\text { journals }\end{array}$ & $\begin{array}{l}\text { Never }=0 \\
<1 / \text { month }=0 \\
>1 / \text { month }=32\end{array}$ & $\begin{array}{l}\text { Never }=0 \\
<1 / \text { month }=3 \\
>1 / \text { month }=35\end{array}$ & $\begin{array}{l}\text { chi-squared = 1.07, } \\
P<0.001\end{array}$ \\
\hline $\begin{array}{l}\text { Postgraduate } \\
\text { courses }\end{array}$ & $\begin{array}{l}\text { None }=0 \\
1 \text { day }=0 \\
2-4 \text { days }=5 \\
5-10 \text { days }=116 \\
11+\text { days }=16\end{array}$ & $\begin{array}{l}\text { None }=0 \\
1 \text { day }=0 \\
2-4 \text { days }=5 \\
5-10 \text { days }=14 \\
11+\text { days }=19\end{array}$ & $\begin{array}{l}\text { chi-squared }=0.38 \text {, } \\
\text { ns }\end{array}$ \\
\hline
\end{tabular}

proportion of each type of practice) working in these three types of dental practice.

For each of the three areas comparisons were made of practitioners defined into two groups for each area. These groups were: General Dental Practice — practice owners versus non-owners; Hospital Dental Service - consultants versus non-consultants; Community Dental Service - directors and senior dental officers versus community dental officers. Comparisons were made between the groups on the following variables:

- Sex (male versus female)

- Age

- Number of years since first qualifying as a dentist

- Number of additional qualifications

- Place of qualification (UK versus non-UK)

- Number of children

- Number of hours worked per week

- Whether the respondent had taken a career break (no breaks vs. at least one break)

- Frequency of reading professional journals

- Number of days attendance at postgraduate courses in the previous year.

The chi-squared statistic was calculated for categorical variables (sex, career break, frequency of reading professional journals, attendance at postgraduate courses, place of qualification). For continuous variables with a normal distribution the t-test was used (age, years of qualification), and for skewed continuous variables the Mann-Whitney $U$-test was calculated (number of additional qualifications, number of children, number of hours worked).

\section{General dental practice}

The outcome variable used in this analysis was ownership of a dental practice - that is being either sole proprietor of, or a partner in, a general dental practice. Female dentists were significantly less likely to be a partner in, or sole proprietor of, a dental practice (chisquared $=170.79, P<0.001)$. A comparison of only those general dental practitioners aged 40 years and younger, revealed that females in this age group were significantly less likely than males of the same age to own their own practice. Of the women in this age group $61(25.3 \%)$ owned practice, in comparison to $219(63.5 \%)$ men (chi-squared $=81.3, P<0.001)$.

Table 2 shows the comparison between practice owners and nonpractice owners on the demographic variables. Practice owners were more likely to be male, older, to have been qualified for a longer period of time, to have an additional qualification, to have more children and to work longer hours. Practice owners were less likely to have taken a career break at any point, and reported reading postgraduate journals more frequently and attending courses more often than non-practice owners.

\section{Hospital dental service}

The outcome variable used in this analysis was consultant position. Consultants were compared with dental practitioners in all other hospital positions. Of those dentists working in the hospital dental service, women were more likely to occupy non-consultant positions (chi-squared $=15.76, P<0.001$ ). Comparing only those individuals under the age of 40 years, there was no significant difference between males and females in the proportion that held consultant positions ( 4 males of a total of 15, 2 females of 23 ; chi-squared $=1.06, \mathrm{~ns}$ ).

Table 3 compares consultants and non-consultants on demographic and working characteristics. Consultants are more likely to be male, older, to have been qualified longer and have a greater number of additional qualifications. Consultants report reading professional journals more often than their junior staff. 


\section{Community dental service}

Directors of community dental services and senior dental officers were grouped together in this analysis and compared with those occupying dental officer positions. A significantly greater proportion of females in this sample occupied community dental officer positions (chi-squared $=4.33, P<0.05$ ). Comparing only those individuals under the age of 40 years, there was no significant difference between males and females in the proportion that held senior positions ( 9 males of a total of 20, 13 females of 41; Chisquared $=0.53, \mathrm{~ns})$.

Table 4 compares the two groups thus defined on all variables. Those occupying senior positions in the community dental service are more likely to be male, are more likely to have an additional postgraduate qualification, report working longer hours and report reading professional journals and attending postgraduate courses more often than those in community dental officer posts.

\section{Discussion}

General dental practice

These findings support those of previous surveys which show that most women (like most men) are employed in general dental practice. Also in keeping with other findings is that women are less likely to be practice owners (sole proprietor or partners) than men. Indeed in McEwen and Seward's 1988 survey, 63\% of practising women dentists were in general practice, of whom just under half were owners. ${ }^{5}$ In our sample $77 \%$ of women dentists were in general practice of whom $38 \%$ were owners. This compares with $90 \%$ of male dentists who worked in general practice, of whom $76 \%$ were owners. Thus both the numbers and the proportion of women dentists in general practice has increased even more sharply than in the previous decades while the proportion of women owners has decreased.

The variables which predict differences between owners and non-owners are number of years qualified (the longer qualified, the likelier you are to own your practice); the hours you work (practice owners work longer hours); number of children (those GDPs who are practice owners have more children) and sex; that is, women are less likely to be practice owners than men.

The findings from this survey indicate Seward and McEwen's 9 prediction that the proportions of women proprietors would decrease has been borne out. In the 1986 survey they suggest that women's reluctance to become proprietors may relate to the rising divorce rate, as business partnerships with husbands can be very difficult to unravel after relationship breakdown. However, as mentioned in the introduction, McEwen and Seward ${ }^{5}$ suggested that the difference in practice ownership may be caused by a combination of women being disinclined to take on the responsibility of practice ownership and to the reluctance of some men to enter into business partnerships with women. It is likely that these are all probable reasons for the difference. However, it may also indicate that women prefer the relative financial security of a non-partner position (ie assistant or associate). A consideration of the employment patterns in the hospital and community service can shed further light on this.

\section{Community dental service (CDS)}

Women in our sample were more likely than men to choose to work in the CDS. While about $18 \%$ of women in our sample were employed by the CDS, only $5 \%$ of men were. This, nevertheless, continues the trend identified by McEwen and Seward. They reported a decrease in the proportion of practising women dentists

\begin{tabular}{|c|c|c|c|}
\hline Variable & $\begin{array}{l}\text { Director/Senior } \\
\text { Dental Officer }(N=58)\end{array}$ & $\begin{array}{l}\text { Community Dental } \\
\text { Officer }(N=76)\end{array}$ & \\
\hline Sex & $\begin{array}{l}\text { Males }=27 \\
\text { Females }=21\end{array}$ & $\begin{array}{l}\text { Males }=31 \\
\text { Females }=55\end{array}$ & $\begin{array}{l}\text { chi-squared = 4.33, } \\
P<0.05\end{array}$ \\
\hline Age & $\begin{array}{l}\text { Mean }=46.71 \text { years } \\
(S D=12.53)\end{array}$ & $\begin{array}{l}\text { Mean }=43.93 \text { years } \\
(S D=11.88)\end{array}$ & $t=1.32, \mathrm{~ns}$ \\
\hline Years qualified & $\begin{array}{l}\text { Mean }=20.37 \text { years } \\
(S D=8.63)\end{array}$ & $\begin{array}{l}\text { Mean }=20.73 \text { years } \\
(S D=11.32)\end{array}$ & $t=0.20, n s$ \\
\hline Additional qualifications & $\begin{array}{l}\text { Mean }=0.73 \\
(S D=0.99)\end{array}$ & $\begin{array}{l}\text { Mean }=0.19 \\
(S D=0.54)\end{array}$ & $\begin{array}{l}U=1691.5 \\
P<0.001\end{array}$ \\
\hline Place of qualification & $\begin{array}{l}\text { UK }=58 \\
\text { Non-UK = } 0\end{array}$ & $\begin{array}{l}\text { UK }=74 \\
\text { Non-UK = } 2\end{array}$ & $\begin{array}{l}\text { chi-squared = 3.46, } \\
\text { ns }\end{array}$ \\
\hline Number of children & $\begin{array}{l}\text { Mean }=2.24 \\
(S D=1.35)\end{array}$ & $\begin{array}{l}\text { Mean }=1.92 \\
(S D=1.18)\end{array}$ & $\mathrm{U}=458, \mathrm{~ns}$ \\
\hline Hours worked & $\begin{array}{l}\text { Mean }=34.56 \\
\text { hours/week }(S D=8.61)\end{array}$ & $\begin{array}{l}\text { Mean }=31.37 \\
\text { hours/week }(S D=9.09)\end{array}$ & $U=1756, P<0.05$ \\
\hline Career break & $\begin{array}{l}\text { Taken break }=23 \\
\text { Not taken a break = } 35\end{array}$ & $\begin{array}{l}\text { Taken break }=40 \\
\text { Not taken a break }=36\end{array}$ & $\begin{array}{l}\text { chi-squared = } 1.73 \text {, } \\
\text { ns }\end{array}$ \\
\hline $\begin{array}{l}\text { Reading } \\
\text { professional } \\
\text { journals }\end{array}$ & $\begin{array}{l}(\text { Never }=0) \\
(<1 / \text { month }=3)^{*} \\
>1 / \text { month }=55\end{array}$ & $\begin{array}{l}(\text { Never }=1) \\
(<1 / \text { month }=15)^{*} \\
>1 / \text { month }=60\end{array}$ & $\begin{array}{l}\text { chi-squared }=5.57 \\
P<0.05\end{array}$ \\
\hline $\begin{array}{l}\text { Postgraduate } \\
\text { courses }\end{array}$ & $\begin{array}{l}(\text { None }=0) \\
(1 \text { day }=3)^{*} \\
2-4 \text { days }=11 \\
5-10 \text { days }=24 \\
11+\text { days }=14\end{array}$ & $\begin{array}{l}(\text { None }=4) \\
(1 \text { day }=3)^{*} \\
2-4 \text { day }=36 \\
5-10 \text { days }=22 \\
11+\text { days }=11\end{array}$ & $\begin{array}{l}\text { chi-squared }=11.24 \\
P<0.05\end{array}$ \\
\hline
\end{tabular}

*Categories joined together for calculation of Chi-square statistic 
employed in the CDS from $42 \%$ in 1975 to $29 \%$ in $1986 .{ }^{5}$ However, despite this decline women are still more likely than men to be employed in the CDS. This may be because there are fewer men than women applying to the CDS, or that men are less likely than women to be successful at interview. Again, it is likely to be a combination of both. However it does point to the possibility that women are more likely than men to choose the more secure salaried positions rather than the uncertainty of running a small business. Another possibility is that, even with its changed role of providing care for patients with special needs, employment in the community dental service may be perceived as a job with a more 'feminine' caring profile. Up until the 1989 reorganisation, the community dental service was still perceived by some to be associated with the previous school dental service with an image of providing dental care for children and the potential to work hours related to the school day.

Women are more likely than men to occupy the lower positions within the CDS, though this difference is most apparent among the older cohort of dental practitioners. Seniority in the CDS is related to longer working hours and the acquisition of postgraduate qualifications. Thus it might be supposed that women are less able to gain additional qualifications than men. As seniority is not related to age, or length of time since qualification, other factors should be sought to explain this finding. It is unlikely that there are inherent differences between men and women that make women more reluctant to gain additional qualifications and so it could be suggested that differences between men's and women's domestic roles underpin this. ${ }^{2,3,5}$

\section{Hospital dental service (HDS)}

A slightly higher percentage of women dentists (5.7\%) than men $(4.8 \%)$ were employed in the hospital dental service, although in actual numbers this represents 28 women and 47 men. Again, men are more likely than women to be employed in the most senior (consultant) positions, though this difference disappears among the younger respondents. Consultant status is related to age, time since qualification and number of additional qualifications. It may well be that with the passage of time there will be more older women in the hospital service and that they will then be able to compete more equally with men for the consultant posts. However, women in the HDS also have fewer additional qualifications than men. Again, as noted above, this may be caused by the difference in their domestic roles.

\section{Conclusion}

In conclusion, it would seem that being a woman has less impact on employment chances in the hospital and the community services in contrast to general practice. This may point to the fact that the salaried services operate within institutions that are obliged to implement fair employment practices, such as equal opportunity policies. It may also reflect a preference among women for employment in these services as they offer better terms and conditions of work, such as maternity benefits and secure employment contracts.

The lack of additional qualifications which appears to be holding women back can perhaps be explained by the expectation that women will combine employment with a responsibility for the family and household. The juggling of these roles has been well documented. ${ }^{2,3,5,9,10}$ It is likely that the opportunity to study is reduced for women because of this.

It would appear, therefore, that women employed in the GDS are less favourably treated than those in the HDS and CDS as it is only in general practice that women, when equal in all other respects to men, do not achieve equally with men. The findings seem to suggest that this might be explained by the lack of both equal opportunities policies and practice and acceptable contracts (eg terms and conditions of service relating to maternity leave etc) within the general dental service. This absence of formal accountable procedures may allow both implicit and explicit (sexist) assumptions about women's expected career prospects to inform appointments procedures. It might also be that women prefer to work as associates since this offers more employment security and flexibility in working hours (even if without the more favourable terms and conditions of the CDS and the HDS). This too may be related to their need to balance employment with their expected domestic role. In addition, there is a suggestion that the proportion of students of Asian backgrounds qualifying in dentistry may be increasing. The impact of ethnicity and sex upon employment status requires further research.

1 Seward M H. The provision of dental care by women dentists in England and Wales in 1975. London: British Postgraduate Medical Federation, 1976.

2 McEwen E M, Seward M H. The contribution of women to dentistry in the 1980s. Br Dent J 1988; 165: 339-341.

3 Matthews R W, Scully C. Working patterns of male and female dentists in the UK. Br Dent J 1994; 176: 463-466.

4 Spencer A J, Lewis J M. The practice of dentistry by male and female dentists. Comm Dent Oral Epidemiology 1988; 16: 202-207.

5 McEwen E M, Seward M H. Women dentists at work. Br Dent J 1988; 165 : 380-382.

6 American Dental Association. A comparative study of male and female dental practice patterns. Chicago: ADA, 1989.

7 Brown L J, Lazar V. Differences in net incomes of male and female owner general practitioners. J Amer Dent Assoc 1988; 129: 373-378.

8 de Wet E, Truter M, Ligthelm A J. Working patterns of male and female dentists in South Africa. J Dent Assoc South Africa 1997; 52: 15-17.

9 Finch J. Married to the job. London: George Allen and Unwin, 1983.

10 Adkins L. Gendered work: sexuality, family and the labour market. Buckingham: Open University Press, 1995.

The authors wish to acknowledge the guidance and support of Dame M. Seward, and the hard work of Ms G. Moriarty, Administrative Assistant, Department of Dental Public Health \& Oral Health Services Research. We are also grateful for the advice of three anonymous referees.

\section{British Dental Journal Publication Times}

The British Detal Journal is pleased to be able to announce that average acceptance to publication times - the period of time after the paper has been refereed and approved until its final appearance in the Journal — remained as fast in the second half of 1999 as in the first half.

Current publications times for the various sections in the Journal are as follows:

Opinion papers - 4 months; Practice papers - 7 months; Research -3 months; and Education -3 months

In some instances the publication times can be substantially faster and we anticipate an improvement in the publication times of practice papers in volume 188. 